\title{
Residual Effects of the Organic Amendments Poultry Litter, Farmyard Manure and Biochar on Soybean Crop
}

\author{
Alexandre Martins Abdão dos Passos ${ }^{*}$, Pedro Milanez de Rezende², \\ Everson Reis Carvalho², Andréia Marcilane Aker ${ }^{3}$ \\ ${ }^{1}$ EMBRAPA Rondônia, Porto Velho, Brazil \\ ${ }^{2}$ Federal University of Lavras (UFLA), Lavras, Brazil \\ ${ }^{3}$ Federal University of Rondonia (UNIR), Rolim de Moura, Brazil \\ Email: ${ }^{*}$ alexandre.abdao@embrapa.br
}

Received 15 October 2014; revised 29 October 2014; accepted 10 November 2014

Copyright (C) 2014 by authors and Scientific Research Publishing Inc.

This work is licensed under the Creative Commons Attribution International License (CC BY).

http://creativecommons.org/licenses/by/4.0/

(c) (i) Open Access

\section{Abstract}

The use of organic wastes, as an alternative to inorganic fertilizer, can be an important strategy for Brazilian and tropical agriculture. Despite the importance, few field studies have been done for evaluating organic amendments on soybean crops in Brazil. The study aimed to evaluate the residual effects of the organic amendments poultry litter, farmyard manure and biochar combined with mineral fertilizer on some agronomic attributes of a soybean crop. A field experiment was carried out in a split-split-plot scheme, with three replicates in a randomized block experimental

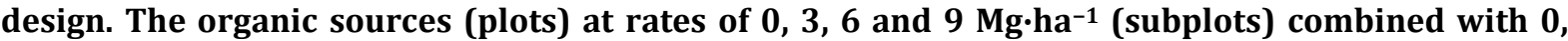
$100,200,300$ and $400 \mathrm{~kg} \cdot \mathrm{ha}^{-1}$ (sub subplots) of a mineral fertilizer were applied in 2008. In 2009, only the mineral fertilizer was used on the soybean crop. As a result, all evaluated attributes were influenced by the treatments, except for the number of grains per pod. The application of poultry litter provided the highest yield (3715 $\mathrm{kg} \cdot \mathrm{ha}^{-1}$ using $9 \mathrm{Mg} \cdot \mathrm{ha}^{-1}$ of the source). A synergistic effect between organic amendments and mineral fertilizer was observed. It was found the possibility of decrease doses of mineral fertilizers by prior use of organic amendments. The most effective dose combination application is $5.5 \mathrm{Mg} \cdot \mathrm{ha}^{-1}$ of organic amendments associated with $200 \mathrm{~kg} \cdot \mathrm{ha}^{-1}$ of mineral fertilizer to provide optimum yield. The use of organic amendments, rich in nutrients, is a technology to sustainably increase the soybean grain yield.

\section{Keywords}

Glycine max, Integrated Production, Organic Wastes, Sustainability, Yield

\footnotetext{
"Corresponding author.
}

How to cite this paper: dos Passos, A.M.A., et al. (2014) Residual Effects of the Organic Amendments Poultry Litter, Farmyard Manure and Biochar on Soybean Crop. Agricultural Sciences, 5, 1376-1383. 


\section{Introduction}

Brazil is an important food producer in the world, standing as the biggest exporter and second producer of soybean [1]. Participation of the Brazilian soybean in world trade is highly significant. The importance of soybeans to Brazil's economy and social status is unmatched amongst others cash crops.

The country is the fourth largest fertilizers consumer market; however, it is only the sixth largest producer in the world. More than half of fertilizers used in the country are imported [2]. In Brazil, the soybean crops are responsible for more than a third of the national demand of mineral fertilizer [2]. Mineral fertilizers represent the major part of the production costs in the soybean crop in Brazil [3].

Considering this, several researchers have focused to create and develop technologies in order to increase fertilizer efficiency and identify alternative sources of nutrients, such as the organic wastes in Brazil and other countries [4]-[7].

Several organic sources have shown potential to provide satisfactory amounts of nutrients to plants [8]. As a rule, this practice is both more profitable and sustainable compared to the application of mineral fertilizers [9]. Some organic wastes have been tested on soybean crops. The use of biosolid as a fertilizer can be feasible, once that is more agronomically efficient than mineral fertilizers [10]. In this sense, soybean yield can be boosted by amendments like flue dust, aqueous lime, sewage sludge and lime use. In addition, the dynamics of nutrients in a soybeans/sorghum intercropping system observed that the application of $75 \%$ mineral NPK combined with chicken manure/farmyard manure/phosphocompost compound is an option of plant nutrition management [11]. In Brazil, poultry litter can be a viable and alternative input to enhance the soybean production and to reduce the production costs [12].

Organic amendments combined with inorganic fertilizer are a promising sustainable technology. Nevertheless, few studies have evaluated the residual effects, over the years, of the organic amendments associated to mineral fertilizer on cash crops. The aim of this study was to evaluate the residual effects of poultry litter, farmyard manure and biochar previous use, with or without mineral fertilizer, on grain yield and others agronomic attributes of soybean plants.

\section{Materials and Methods}

The experiment was carried out in Itutinga, located in Minas Gerais Province ( $21^{\circ} 23$ 'S, $44^{\circ} 39^{\prime} \mathrm{W}$; 958 m.a.s.l.), in Brazil, over a two-year period. According to the climatic classification of Köppen, the climate is classified as Cwa type with humid summers and dry winters [13]. The temperatures and precipitation during the experiment are shown in Figure 1.

A randomized complete block design, with three replicates in split-split-plot scheme was used. The treatments applied to whole plots were the organic sources: poultry litter (PL), farmyard cattle manure (FM) and biochar (BC). The organic sources were manually spreaded and incorporated into the soil with a harrow, in the previous

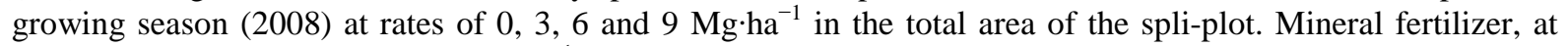
rates of $0,100,200,300$ and $400 \mathrm{~kg} \cdot \mathrm{ha}^{-1}$, had been used and manually applied to the sub-subplot furrow at sowing time, in both seasons (2008 and 2009). The standard sowing fertilization was based on soil analysis and interpretations according to [14], by use of $400 \mathrm{~kg} \cdot \mathrm{ha}^{-1}$ of 04-30-10 NPK mineral fertilizer with 6.10 of Ca, 2.97 of S, 0.06 of B, 0.97 of $\mathrm{Mn}$ and $0.31 \%$ of $\mathrm{Zn}$.

The soybean seeds, of cultivar "BRS Favorite", have been previously inoculated with Bradyrhizobium japonica, using the ratio of 1,200,000 bacteria per seeds. The sub subplots consisted of four rows, five meters long, with fifty $\mathrm{cm}$ between-row spacing. The physicochemical properties of the organic amendments are given in Table 1.

The experiment was carried out in a Dystrophic Cambisol (Inceptisol) [15], with a clay texture (53\% clay); a low fertility soil: $\mathrm{pH}$ in water 5.4; P (Mehlich 1) $2.0 \mathrm{mg} \cdot \mathrm{dm}^{-3} ; \mathrm{K} 98.0 \mathrm{mg} \cdot \mathrm{dm}^{-3} ; \mathrm{Ca}^{2+} 1.5 \mathrm{cmolc} \cdot \mathrm{dm}^{-3} ; \mathrm{Mg}^{2+} 0.4$ cmolc $\cdot \mathrm{dm}^{-3} ; \mathrm{Al}^{3+} 0.2 \mathrm{cmolc} \cdot \mathrm{dm}^{-3}$; sum of bases $2.2 \mathrm{cmolc} \cdot \mathrm{dm}^{-3}$; cation exchange capacity (effective) $2.4 \mathrm{cmolc}$. $\mathrm{dm}^{-3}$; base saturation $35.0 \%$; organic matter $40.0 \mathrm{~g} \cdot \mathrm{kg}^{-1}$; sand $310 \mathrm{~g} \cdot \mathrm{kg}^{-1}$ and clay $400 \mathrm{~g} \cdot \mathrm{kg}^{-1}$.

At harvest, R8 phase [16], the attributes: number of pods per plant, number of grains per pod (10 plants sampled in the sub subplots), weight of 100 grains, grain yield (13\% moisture), plant height and first pod height (10 randomly selected plants were sampled) were evaluated.

The data were analyzed using the Sisvar ${ }^{\circledR}$ software [17]. The significant effects were submitted to regression analysis for the doses of organic amendments and NPK fertilizer. The response surfaces were obtained and in- 


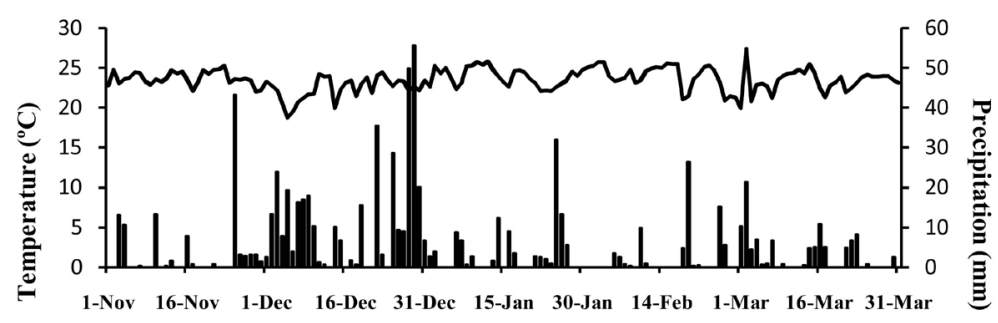

Figure 1. Mean temperature $\left({ }^{\circ} \mathrm{C}\right)$ and precipitation $(\mathrm{mm})$ between November 2009 and April 2010. Engineering Department, Federal University of Lavras, Brazil.

Table 1. Physiochemical analysis of the poultry litter (PL), farmyard manure (FM) and biochar (BC).

\begin{tabular}{ccccc}
\hline Parameters & Units & Results & BC \\
\cline { 3 - 4 } pH in water & - & PL & FM & 7.30 \\
Electrical conductivity (EC) & $\mathrm{dS} \cdot \mathrm{m}^{-1}$ & 26.40 & 19.00 & 2.90 \\
Water retention capacity & $\mathrm{ml} \cdot \mathrm{g}^{-1}$ & 2.10 & 1.80 & 0.80 \\
Apparent density & $\mathrm{g} \cdot \mathrm{cm}^{-3}$ & 0.40 & 0.40 & 0.80 \\
Total carbon & $\mathrm{g} \cdot \mathrm{kg}^{-1}$ & 411.00 & 285.00 & 191.00 \\
Organic matter (OM) & $\mathrm{g} \cdot \mathrm{kg}^{-1}$ & 820.00 & 570.00 & 380.00 \\
Total nitrogen (N) & $\mathrm{g} \cdot \mathrm{kg}^{-1}$ & 44.00 & 24.00 & 5.00 \\
N-ammonium & $\mathrm{mg} \cdot \mathrm{kg}^{-1}$ & 362.00 & 70.00 & 26.00 \\
N-nitrate & $\mathrm{mg} \cdot \mathrm{kg}^{-1}$ & 82.00 & 624.00 & 178.00 \\
Total phosphorus (P) & $\mathrm{g} \cdot \mathrm{kg}^{-1}$ & 8.50 & 1.10 & 0.40 \\
Total potassium (K) & $\mathrm{g} \cdot \mathrm{kg}^{-1}$ & 37.00 & 19.60 & 2.60 \\
Sodium (Na) & $\mathrm{g} \cdot \mathrm{kg}^{-1}$ & 4.50 & 0.90 & 0.40 \\
Calcium (Ca) & $\mathrm{g} \cdot \mathrm{kg}^{-1}$ & 31.00 & 9.50 & 13.00 \\
Magnesium (Mg) & $\mathrm{g} \cdot \mathrm{kg}^{-1}$ & 11.50 & 5.40 & 2.30 \\
Sulfur (S) & $\mathrm{mg} \cdot \mathrm{kg}^{-1}$ & 6.20 & 2.70 & 0.00 \\
Boron (B) & $\mathrm{mg} \cdot \mathrm{kg}^{-1}$ & 46.70 & 13.00 & 0.00 \\
Copper (Cu) & $\mathrm{mg} \cdot \mathrm{kg}^{-1}$ & 119.00 & 30.00 & 19.00 \\
Iron (Fe) & $\mathrm{mg} \cdot \mathrm{kg}^{-1}$ & 2324.00 & 14.56 & 354.60 \\
Manganese (Mn) & $\mathrm{mg} \cdot \mathrm{kg}^{-1}$ & 691.00 & 232.00 & 1107.00 \\
Zinc (Zn) & $\mathrm{mg} \cdot \mathrm{kg}^{-1}$ & 624.00 & 82.00 & 371.00 \\
\hline
\end{tabular}

*Analyses performed at the Soil Science Department of Federal University of Lavras.

terpreted using the statistical package software Statistica ${ }^{\circledR} 6.0$ for Windows.

\section{Results and Discussion}

All evaluated attributes were influenced by the treatments, except the number of grains per pod (Table 2). This attribute has a high genetic control being weakly responsive to environmental variation [18].

A triple interaction among the organic sources, their doses and mineral fertilizer doses was observed on the grain yield (Table 2). The effects of the organic amendments doses for each source were evaluated through the response surface methodology [19].

The biochar and the farmyard manure provided similar effect on the yield. The effects of mineral fertilizer doses were more expressive than the organic doses on the grain yield (Figure 2). On the other hand, a larger synergistic effect between the poultry litter doses and mineral fertilizer doses were detected. In this organic source, it was possible to achieve the highest yield levels $\left(>4000 \mathrm{~kg} \cdot \mathrm{ha}^{-1}\right)$ using only $9 \mathrm{Mg} \cdot \mathrm{ha}^{-1}$; while for the biochar and farmyard manure, the increments were significantly lower than that (2000 and $1500 \mathrm{~kg} \cdot \mathrm{ha}^{-1}$, respectively). In both residues (FM and BC), the lower grain yield may be explained due the lower supply of nutrients 
Table 2. Summary of the analysis of variance for grain yield (GY), number of pods per plant (PP), number of grains per pod (GP), weight of 100 grains (WG), plant height (PH) and first pod height (FP) obtained in the experiment organic amendments and mineral fertilizer on soybean crop.

\begin{tabular}{|c|c|c|c|c|c|c|c|}
\hline \multirow{2}{*}{ Source } & \multirow{2}{*}{ DF } & \multicolumn{6}{|c|}{ Mean Square } \\
\hline & & GY & PP & GP & WG & $\mathrm{PH}$ & FP \\
\hline Sources (S) & 2 & $8185322.46^{*}$ & 123.7905 & 0.0436 & $3.0209^{\S}$ & $1626.5389^{*}$ & 18.4389 \\
\hline Error 1 & 4 & 784697.12 & 81.1228 & 0.0189 & 0.4482 & 216.5722 & 33.1556 \\
\hline Organic (D1) & 3 & $4849677.82^{* *}$ & $655.2085^{* *}$ & 0.0339 & $30.3862^{* *}$ & $546.9704 \S$ & 3.3537 \\
\hline $\mathrm{S} \times \mathrm{D} 1$ & 6 & $2238745.74^{* *}$ & 74.9683 & 0.0187 & $1.0769 \S$ & 280.6426 & 18.1649 \\
\hline Error 2 & 18 & 394455.60 & 94.0005 & 0.0166 & 0.4091 & 215.3074 & 31.2500 \\
\hline NPK (D2) & 4 & $15385770.98^{* *}$ & $839.5845^{* *}$ & 0.0154 & $12.2767^{* *}$ & $1597.9111^{* *}$ & $38.5083^{*}$ \\
\hline $\mathrm{S} \times \mathrm{D} 2$ & 8 & $634253.48^{* *}$ & 71.7727 & 0.0131 & $1.3439^{* *}$ & $75.4694^{\S}$ & 10.9250 \\
\hline $\mathrm{D} 1 \times \mathrm{D} 2$ & 12 & $347592.12^{\S}$ & 61.8711 & 0.0335 & $2.4604 \S$ & 30.1000 & 8.9972 \\
\hline $\mathrm{S} \times \mathrm{D} 1 \times \mathrm{D} 2$ & 24 & $342170.26^{*}$ & 73.2197 & 0.0293 & $1.1400^{*}$ & $60.5917^{\S}$ & 15.6972 \\
\hline Error 3 & 96 & 192403.86 & 52.8298 & 0.0241 & 0.6828 & 39.1667 & 13.9236 \\
\hline \multicolumn{8}{|c|}{ Coefficient of Variation (CV) } \\
\hline CV $1(\%)$ & & 31.23 & 32.23 & 6.71 & 4.67 & 21.29 & 22.81 \\
\hline CV $2(\%)$ & & 22.14 & 34.69 & 6.28 & 4.46 & 21.23 & 22.15 \\
\hline CV 3 (\%) & & 15.47 & 26.01 & 7.57 & 5.76 & 9.05 & 14.78 \\
\hline
\end{tabular}

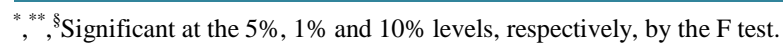

GY $\left(\mathrm{kg} \mathrm{ha}^{-1}\right)=1167.80+392.99^{*} \mathrm{X}+7.31^{*} \mathrm{y}-12.21^{*} \mathrm{X}^{*} \mathrm{X}-0.48^{*} \mathrm{X}^{*} \mathrm{y}-0.0055^{*} \mathrm{y}^{*} \mathrm{Y}$

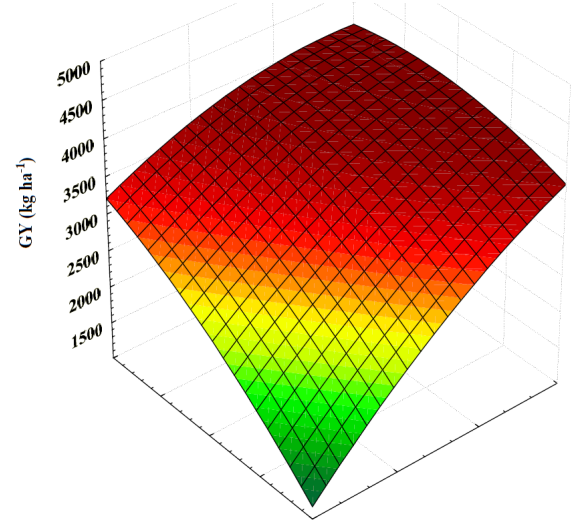

GY $\left(\mathrm{kg} \mathrm{ha}^{-1}\right)=1251.16+71.48^{*} \mathrm{x}+7.38^{*} \mathrm{y}+1.38^{*} \mathrm{x}^{*} \mathrm{x}-0.21^{*} \mathrm{x}^{*} \mathrm{y}-0.0033^{*} \mathrm{y}^{*} \mathrm{y}$

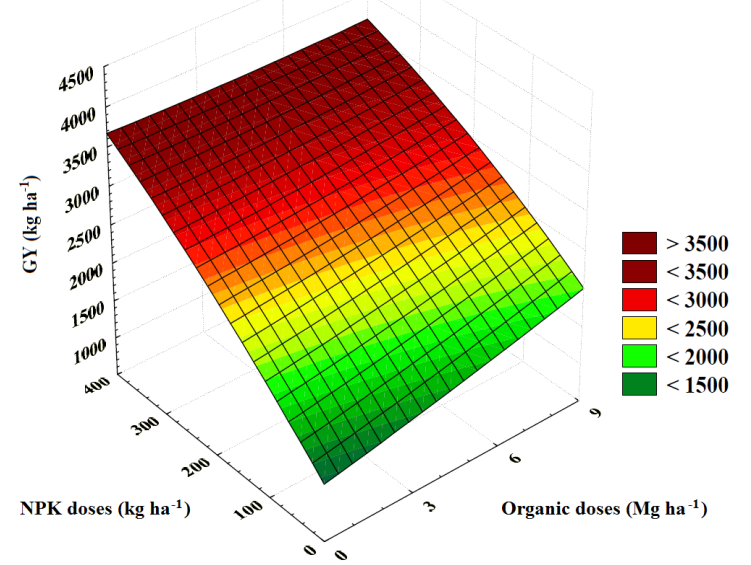

Figure 2. Response surface for residual effects of the organic amendments sources and doses and the mineral fertilizer doses uses on the soybean grain yield.

GY $\left(\mathrm{kg} \mathrm{ha}^{-1}\right)=1428.56-26.40^{*} \mathrm{x}+9.52^{*} \mathrm{y}+5.36^{*} \mathrm{x}^{*} \mathrm{x}-0.0042^{*} \mathrm{x}^{*} \mathrm{y}-0.0138^{*} \mathrm{y}^{*} \mathrm{y}$

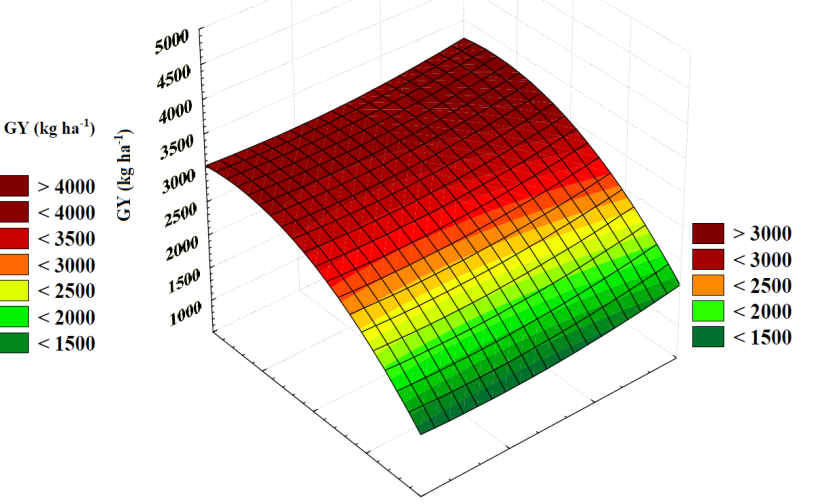

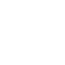


to the soil, allocated by these wastes, in the studied doses. This fact justifies the need for further works considering the use of higher doses. When in suitable amount, biochar use can enhance agro ecosystems. Converting agricultural wastes into a useful soil amendment that holds carbon and makes soils more fertile, avoiding the deforestation and improving the food security [20] [21].

Through the response surfaces is observed that the best dose combination was the application of $5.49 \mathrm{Mg} \cdot \mathrm{ha}^{-1}$ of either organic amendments combined with $200 \mathrm{~kg} \cdot \mathrm{ha}^{-1}$ of the mineral fertilizer; in order to obtain 2792; 2796 and $3672 \mathrm{~kg} \cdot \mathrm{ha}^{-1}$ of soybean grains obtained by the farmyard manure, biochar and poultry litter use, respectively. The best yield obtained through poultry litter use might be due to higher concentration of nutrients in this input, providing higher residual effect on soybean crop. Once soybean plants are highly responsive to nutrient supply [22], mainly in dystrophic tropical soils and in agro ecosystems which have high levels of productivity, given the high nutrient demand for biomass production [23] [24].

These results are consistent with other studies that, by poultry litter use on soybean, also reported increases on grain yield [12] [25]. This fact demonstrates the high potential of the combined use of mineral fertilizers with organic amendments, as a synergistic way to increase the soybean grain productivity [9] [26].

In this study, the number of pods increased as a result of increases in organic rates of the amendments applied in the previous growth season and mineral fertilizer, in 2009 (Figure 3).

In the grain yield, one of the most important factors is the number of pods per plant. In soybean, the adequate plant nutrition is essential for enhance the pod set, which requires adequate availability of nutrients and assimilates in soybean plants [22]. These results are consistent with other studies, which it was observed a positive and high correlation between organic and mineral fertilizer use on number of pods per plants [21] [26].

The application of the organic amendments and mineral fertilizer influenced the grain weight (Figure 4(a)). It is observed that highest weights were obtained by increasing the doses in both inputs. This result is consistent with the findings by other authors evaluating the effect of organic and mineral fertilizers on soybean plants; hence, demonstrating that for tropical soils, generally low fertility, the major factor in the intensification of agricultural production is the adequate soil fertilization and consequent plant nutrition [8] [26]. The best combination of doses in each organic amendments was the same previously observed for the grain yield $\left(200 \mathrm{~kg} \cdot \mathrm{ha}^{-1}\right.$ of the mineral fertilizer associated with $5.5 \mathrm{Mg}$ of the organic amendments) in order to obtain the weight of 100 grains of 14.2; 14.3 and $14.9 \mathrm{~g}$, by the farmyard manure, biochar and the poultry litter addition, respectively. The poultry litter provided greater weight of 100 grains than the farmyard manure and the biochar, rendering the maximum weighs of 16 g per 100 grains when were combined $100 \mathrm{~kg} \cdot \mathrm{ha}^{-1}$ of mineral fertilizer with $9 \mathrm{Mg}$ of the organic input. Adequate plant nutrition is important for grains and seeds filling and, consequently, weight of them. According [27], seed size positively affects the productivity of soybean due to better plant stand and consequent establishment of the crop in the field, especially if sowing is done under water stress conditions [28].

Plant height was also influenced by the levels of organic amendments and mineral fertilizer (Figure 4(b)).

It was found greater plants growth with increasing doses. The maximum plants height, of 77.9, 76.8 and 65.1 $\mathrm{cm}$, were obtained by the doses of 5.50, 3.51 and $7.23 \mathrm{Mg} \cdot \mathrm{ha}^{-1}$ of poultry litter, biochar and farmyard manure associated with 200, 200 and $346.8 \mathrm{~kg} \cdot \mathrm{ha}^{-1}$ of mineral fertilizer (Figure 4(b)). Without mineral fertilizer, it was observed little influence of the farmyard manure and biochar doses on this attribute (green area on the response surface).

The doses of mineral fertilizer influenced the height of first pod (Figure 5).

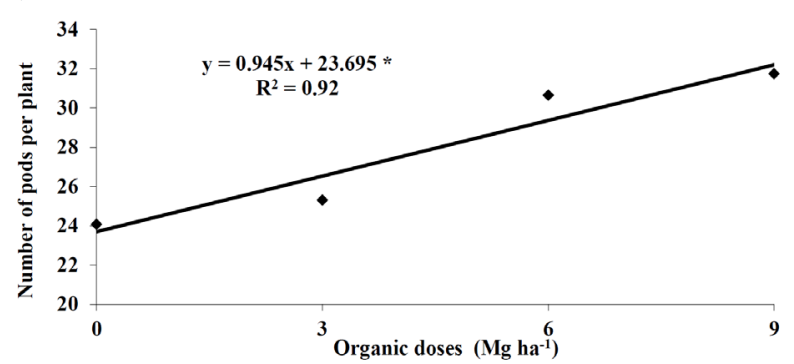

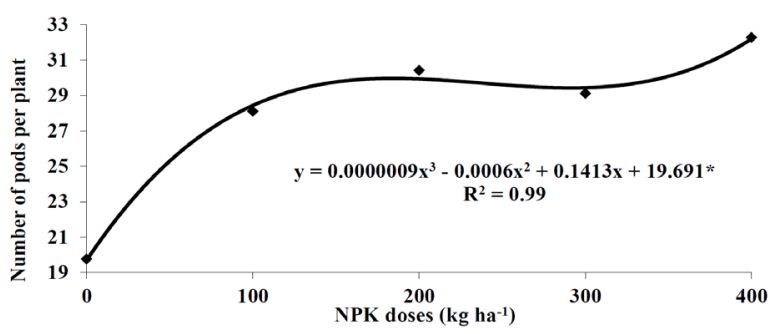

Figure 3. Regression analysis for the number of pods per plants due to the organic amendments doses a) and the mineral fertilizer doses b) on soybean plants. *Significant at the $1 \%$ level, by the $\mathrm{F}$ test $(\mathrm{p} \leq 0.01)$. 


\section{BIOCHAR}

a)

$\mathrm{WG}(\mathrm{g})=13.52-0.048 * \mathrm{x}-3.35 \mathrm{E}-5 * \mathrm{y}+0.0094 * \mathrm{x}^{*} \mathrm{x}+0.0005 * \mathrm{x}^{*} \mathrm{y}+3.72 \mathrm{E}-6^{*} \mathrm{y}^{*} \mathrm{y}$

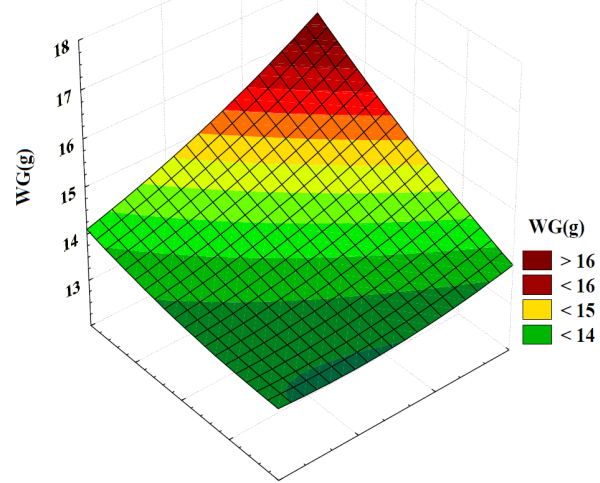

b)

$\operatorname{PH}(\mathrm{cm})=51.73+1.52 * \mathrm{x}+0.11^{*} \mathrm{y}-0.15^{*} \mathrm{x}^{*} \mathrm{x}+0.002^{*} \mathrm{x}^{*} \mathrm{y}-0.0002^{*} \mathrm{y}^{*} \mathrm{y}$

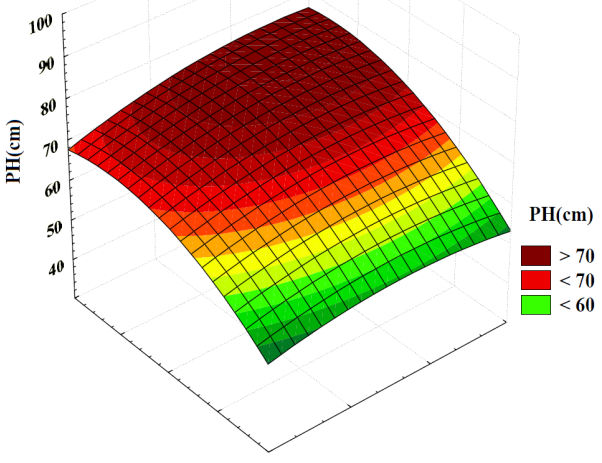

FARMYARD MANURE

$\mathrm{WG}(\mathrm{g})=13.44-0.08^{*} \mathrm{x}-0.0006^{*} \mathrm{y}+0.0117^{*} \mathrm{x}^{*} \mathrm{x}+0.0008^{*} \mathrm{x}^{*} \mathrm{y}+1.0833 \mathrm{E}-6^{*} \mathrm{y}^{*} \mathrm{y}$

$\mathrm{PH}(\mathrm{cm})=57.34-1.75^{*} \mathrm{x}+0.072 * \mathrm{y}^{*}+0.1733^{*} \mathrm{x}^{*} \mathrm{x}+0.0008^{*} \mathrm{x}^{*} \mathrm{y}-0.000008^{*} \mathrm{y}^{*} \mathrm{y}$
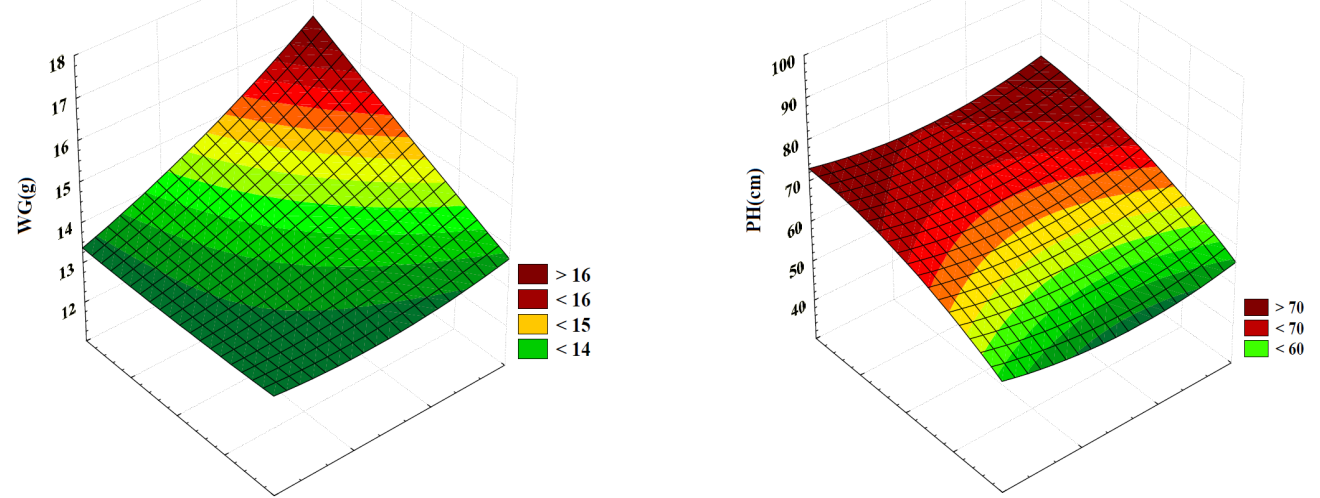

POULTRY LITTER

WG $(\mathrm{g})=12.59+0.1082 * \mathrm{x}+0.0072 * \mathrm{y}+0.0174 * \mathrm{x}^{*} \mathrm{x}+0.0002 * \mathrm{x}^{*} \mathrm{y}-1.0167 \mathrm{E}-5^{*} \mathrm{y}^{*} \mathrm{y}$

$\mathrm{PH}(\mathrm{cm})=52.88+2.44^{*} \mathrm{x}+0.1075^{*} \mathrm{y}+0.1107^{*} \mathrm{x}^{*} \mathrm{x}-0.008^{*} \mathrm{X}^{*} \mathrm{y}-0.0001^{*} \mathrm{y}^{*} \mathrm{y}$
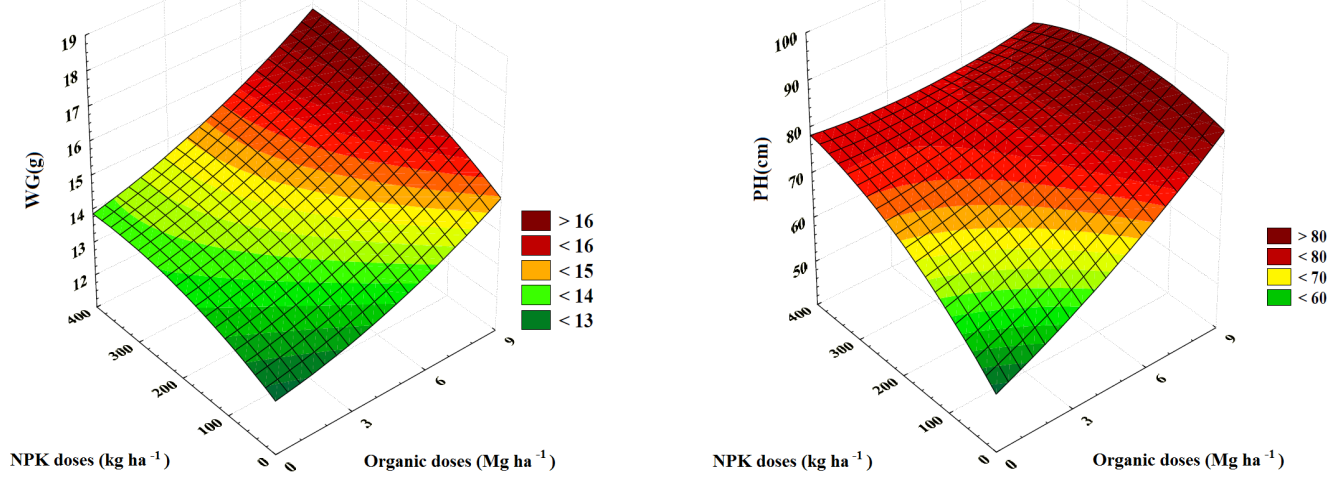

Figure 4. Response surface for residual effects of the organic amendments sources and doses and the mineral fertilizer doses on the weight of 100 grains (WG) a) and plant height (PH) b). 


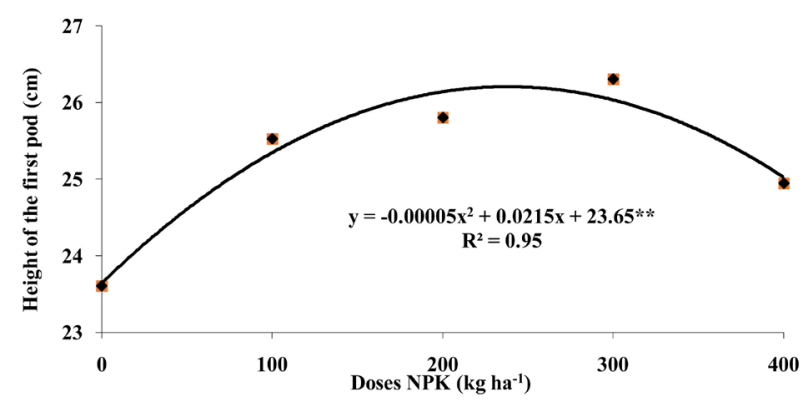

Figure 5. Regression analysis for the height of the first pod due to mineral fertilizer doses on soybean plants. ${ }^{* *}$ Significant at the $5 \%$, by the $\mathrm{F}$ test.

The maximum height of first pod $(26 \mathrm{~cm})$ was obtained using $215 \mathrm{~kg} \cdot \mathrm{ha}^{-1}$ of the mineral fertilizer. The lowest observed height $(23.6 \mathrm{~cm})$ is appropriate to mechanical harvesting machines.

Several agronomic attributes of soybean, included grain productivity, can be expected to differ in response to organic and inorganic fertilization due the fertilizer sources, soil types, application rates and meteorological conditions [8] [20] [24]. Therefore, more studies should be done in order to determine the best and sustainable management practices of these inputs in the specifics conditions and regions [29] [30].

\section{Conclusions}

The best combination of the organic amendments and mineral fertilizer was the same for the grain yield and weight of 100 grains (200 kg ha ${ }^{-1}$ of the mineral fertilizer associated with $5.5 \mathrm{Mg}$ of the organic amendments).

It is possible to decrease the dose of mineral fertilizers, by prior use of poultry litter, maintaining or boosting the levels of grain yield.

The previous use of organic amendments, rich in nutrients, is a promising technology to sustainably increase the soybean grain yield.

\section{References}

[1] FAO (2014) Food and Agriculture Organization of United Nations Statistics FAOSTAT. http://faostat3.fao.org/

[2] ANDA (2010) Anuário estatístico do setor de fertilizantes. São Paulo, Brazil.

[3] de Castro, S.H., Reis, R.P. and Lima, A.L.R. (2006) Custos de produção da soja cultivada sob sistema de plantio direto: Estudo de multicasos no oeste da Bahia. Ciência e Agrotecnologia, 30, 1146-1153. http://dx.doi.org/10.1590/S1413-70542006000600017

[4] Szogi, A.A., Bauer, J.P. and Vanotti, E.M.B. (2010) Fertilizer Effectiveness of Phosphorus Recovered from Broiler Litter. Agronomy Journal, 102, 723-727. http://dx.doi.org/10.2134/agronj2009.0355

[5] Tagoe, S.O., Horiuchi, T. and Matsui, E.T. (2010). Effects of Carbonized Chicken Manure on the Growth, Nodulation, Yield, Nitrogen and Phosphorus Contents of Four Grain Legumes. Journal of Plant Nutrition, 33, 684-700. http://dx.doi.org/10.1080/01904160903575915

[6] Bungenstab, E., Pereira Jr., A., Lin, J., Holliman, J. and Muntifering, R. (2013) Productivity and Nutritive Quality of Dallisgrass (Paspalum dilatatum) as Influenced by Cutting Height and Rate of Fertilization with Poultry Litter or Commercial Fertilizer. Agricultural Sciences, 4, 455-465. http://dx.doi.org/10.4236/as.2013.49061

[7] Moreira, R.A., Ramos, J.D., Araújo, N.A., Marques, V.B. and Melo, P.C. (2012) Produtividade e teores de nutrientes em cladódios de pitaia vermelha utilizando-se adubação orgânica e granulado bioclástico. Revista Brasileira de Ciências Agrárias (Agrária), 7, 714-719. http://dx.doi.org/10.5039/agraria.v7isa1551

[8] Diacono, M. and Montemurro, F. (2010) Long-Term Effects of Organic Amendments on Soil Fertility. A Review. Agronomy for Sustainable Development, 30, 401-422. http://dx.doi.org/10.1051/agro/2009040

[9] Bhattacharyya, R.P.S.C., Chandra, S., Kundu, S., Supradip, S., Mina, B.L., Srivastva, A.K. and Gupta, H. (2010) Fertilization Effects on Yield Sustainability and Soil Properties under Irrigated Wheat-Soybean Rotation of an Indian Himalayan Upper Valley. Nutrient Cycling in Agroecosystems, 86, 255-268. http://dx.doi.org/10.1007/s10705-009-9290-7

[10] Lemainski, J. and da Silva, J.E. (2006) Avaliação agronômica e econômica da aplicação de biossólido na soja. 
Pesquisa Agropecuária Brasileira, 41, 1477-1484. http://dx.doi.org/10.1590/S0100-204X2006001000004

[11] Corrêa, J.C., Büll, L.T., Crusciol, C.A.C. and Tecchio, M.A. (2008) Aplicação superficial de escória, lama cal, lodos de esgoto e calcário na cultura da soja. Pesquisa Agropecuária Brasileira, 43, 1209-1219. http://dx.doi.org/10.1590/S0100-204X2008000900016

[12] Ragagnin, V.A., Sena Jr., D.G., Dias, D.S., Braga, W.F. and Nogueira, P.D.M. (2013) Growth and Nodulation of Soybean Plants Fertilized with Poultry Litter. Ciência e Agrotecnologia, 37, 17-24. http://dx.doi.org/10.1590/S1413-70542013000100002

[13] Dantas, A.A.A., de Carvalho, L.G. and Ferreira, E. (2007) Classificação e tendências climáticas em Lavras, MG. Ciência e Agrotecnologia, 31, 1862-1866. http://dx.doi.org/10.1590/S1413-70542007000600039

[14] Ribeiro, A.C., Guimarães, P.T.G. and Alvarez, V.V.H. (1999) Recomendação para o uso de corretivos e fertilizantes em Minas Gerais: $5^{a}$ aproximação. Comissão de Fertilidade do Solo do Estado de Minas Gerais, Viçosa.

[15] EMPRESA BRASILEIRA DE PESQUISA AGROPECUÁRIA. Centro Nacional de Pesquisa de Solos (2006) Sistema brasileiro de classificação de solos. 2nd Edition, Rio de Janeiro.

[16] Fehr, W.R., Caviness, C.E., Burmood, D.T. and Pennington, J.S. (1971) Stage of Development Descriptions for Soybeans, Glycine max (L.) Merril. Crop Science, 11, 929-931. http://dx.doi.org/10.2135/cropsci1971.0011183X001100060051x

[17] Ferreira, D.F. (2011) Sisvar: A Computer Statistical Analysis System. Ciência e Agrotecnologia, 35, 1039-1042.

[18] Ritchie, S.W., Hanway, J.J., Thompson, H.E. and Benson, G.O. (1997) How a Soybean Plant Develops. Special Report 53, Iowa State University of Science and Technology Cooperative Extension Service, Ames, 20 p.

[19] Custódio, T.N., Morais, A.R. and Muniz, J.A. (2000) Superfície de resposta em experimento com parcelas subdivididas. Ciência e Agrotecnologia, 24, 1008-1023.

[20] Sohi, S.P., Krull, E., Lopez-Capel, E. and Bol, R. (2010) A Review of Biochar and Its Use and Function in Soil. Advances in Agronomy, 105, 47-82. http://dx.doi.org/10.1016/S0065-2113(10)05002-9

[21] Suppadit, T., Phumkokrak, N. and Poungsuk, P. (2012) The Effect of Using Quail Litter Biochar on Soybean (Glycine max L. Merr.) Production. Chilean Journal of Agricultural Research, 72, 244-251. http://dx.doi.org/10.4067/S0718-58392012000200013

[22] Gonçalves Júnior, A.C., Nacke, H., Maregoni, N.G., Carvalho, E.A. and Coelho, G.F. (2010) Produtividade e componentes de produção da soja adubada com diferentes doses de fósforo, potássio e zinco. Ciência e Agrotecnologia, 34, 660-666. http://dx.doi.org/10.1590/S1413-70542010000300019

[23] Bianco, S., Pitelli, R.A. and Carvalho, L.B. (2007) Estudo comparativo do acúmulo de massa seca e macronutrientes por plantas de Glycine max (L.) Merr. e Euphorbia heterophylla L. Ensaios e Ciência, 11, 61-72.

[24] EMBRAPA (2008) Tecnologias de produção de soja—Região central do Brasil 2009 e 2010. Embrapa Soja, Londrina.

[25] Carvalho, E.R., Rezende, P.M., Andrade, M.J.B., Passos, A.M.A. and Oliveira, J.A. (2011) Fertilizante mineral e resíduo orgânico sobre características agronômicas da soja e nutrientes no solo. Revista Ciência Agronômica, 42, 930939. http://dx.doi.org/10.1590/S1806-66902011000400015

[26] Mandal, K.G., Hati, K.M. and Misra, E.A.K. (2009) Biomass Yield and Energy Analysis of Soybean Production in Relation to Fertilizer-NPK and Organic Manure. Biomass and Bioenergy, 33, 1670-1679. http://dx.doi.org/10.1016/j.biombioe.2009.08.010

[27] Krzyzanowski, F.C., França-Neto, J.B. and Costa, N.P. (1991) Efeito da classificação de sementes de soja por tamanho sobre sua qualidade e a precisão de semeadura. Revista Brasileira de Sementes, 13, 59-68.

[28] Madanzi, T., Chiduza, C. and Richardson-Kageler, S.J. (2010) Effects of Planting Method and Seed Size on Stand Establishment of Soybean [Glycine max (L.) Merrill cv. Solitaire]. Soil and Tillage Research, 106, 171-176. http://dx.doi.org/10.1016/j.still.2009.12.003

[29] de Melo Carvalho, M.T., Madari, B.E., Bastiaans, L., Oort, P.A.J.V., Heinemann, A.B., da Silva, M.A.S., de Holanda Nunes Maia, A. and Meinke, H. (2013) Biochar Improves Fertility of a Clay Soil in the Brazilian Savannah: Short Term Effects and Impact on Rice Yield. Journal of Agriculture and Rural Development in the Tropics and Subtropics, 114, 101-107.

[30] Woods, W.I., Falcão, N.P. and Teixeira, W.G. (2006) Biochar Trials Aim to Enrich Soil for Smallholders. Nature, 443, 144. http://dx.doi.org/10.1038/443144b 
Scientific Research Publishing (SCIRP) is one of the largest Open Access journal publishers. It is currently publishing more than 200 open access, online, peer-reviewed journals covering a wide range of academic disciplines. SCIRP serves the worldwide academic communities and contributes to the progress and application of science with its publication.

Other selected journals from SCIRP are listed as below. Submit your manuscript to us via either submit@scirp.org or Online Submission Portal.
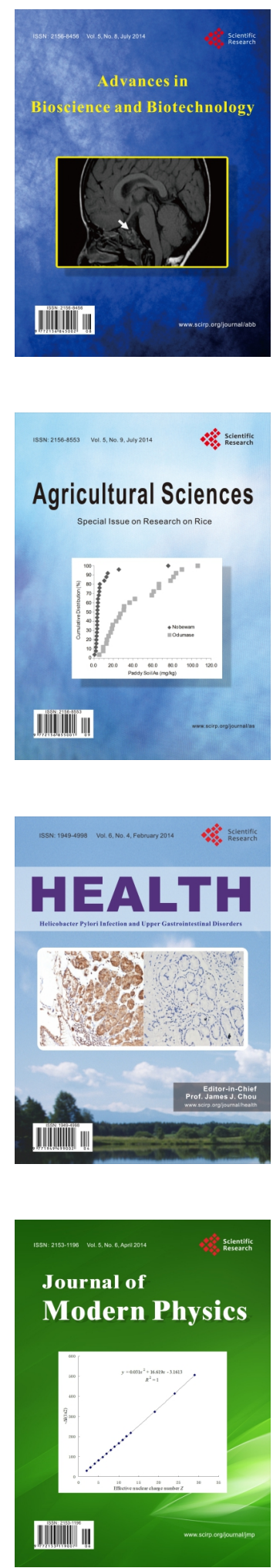
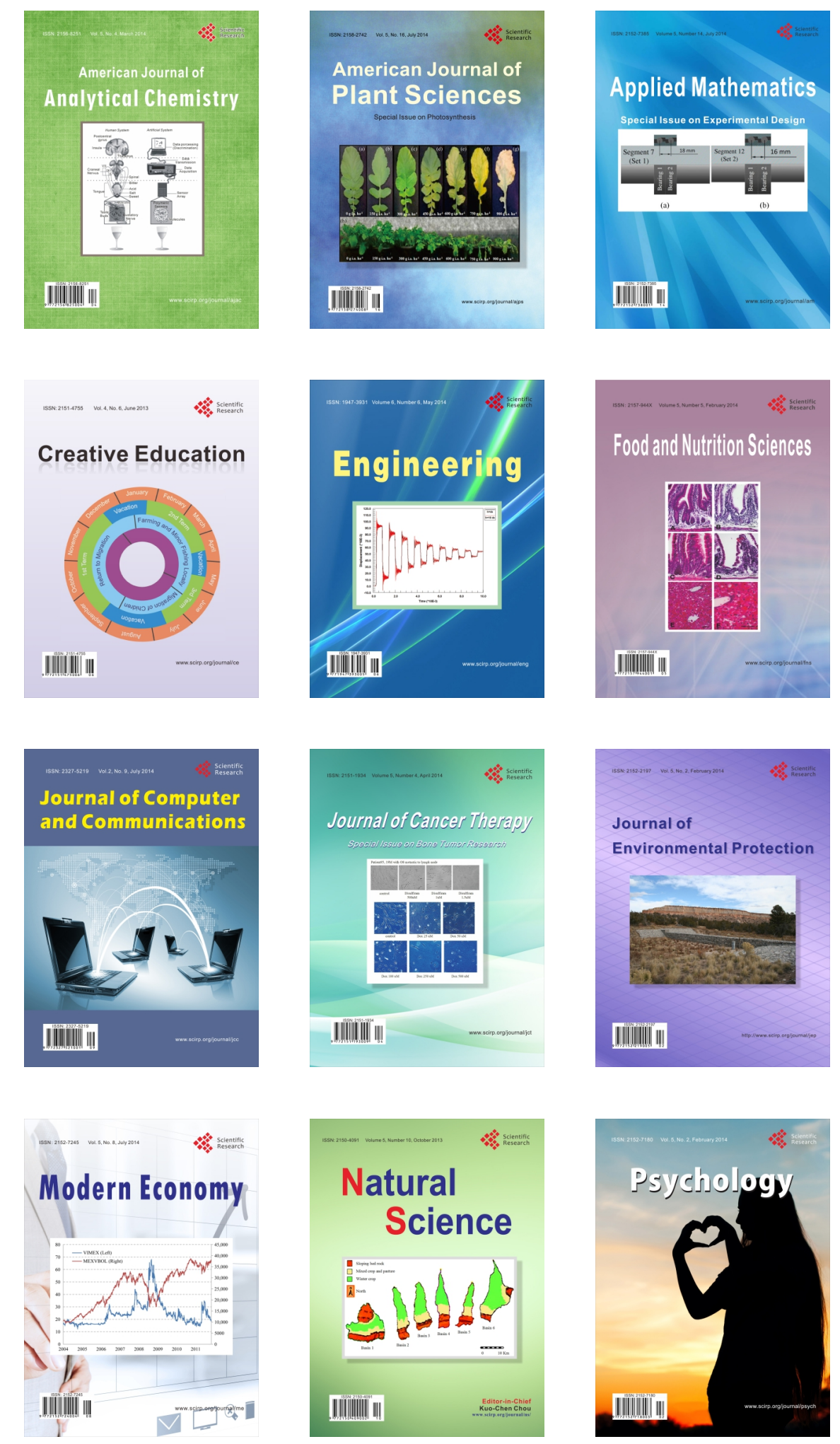